\title{
Migration of intraocular silicone oil into brain
}

\author{
Janaki Gnanalingham, ${ }^{1}$ Rob Mcreary, ${ }^{2}$ Stephen Charles, ${ }^{1}$ Kanna K Gnanalingham ${ }^{2}$
}

${ }^{1}$ Central Manchester University Hospitals NHS Foundation Trust, Manchester, UK

${ }^{2}$ Salford Royal NHS Foundation Trust, Salford, Salford, UK

\section{Correspondence to}

Dr Janaki Gnanalingham, janaki. kanna@gmail.com

Accepted 4 July 2017

\section{DESCRIPTION}

An 84 -year-old woman was admitted following a slight mechanical fall while she was in her garden. She had banged the back of her head followed by a brief period of nausea and vomiting which was self-limiting.

One year before, the patient underwent surgical repair for retinal detachment of left eye with involvement of the macula. She underwent a vitrectomy, endolaser therapy and injection of silicone oil into the vitreous. There was no recovery of vision in the left eye. Medical history included hypertension and bilateral glaucoma.

On examination, she looked well. She had no light perception in the left eye and the visual acuity in the right eye was $\mathrm{N} 10$ on the near reading chart with normal peripheral fields of vision. She was managed conservatively but died shortly due to bowel ischaemia, that was unrelated to her presentation.

A CT scan of brain at presentation revealed hyperdensity in the left globe (figure 1A), that on closer examination could be seen tracking back along left optic nerve and optic chiasm (figure 1B) and
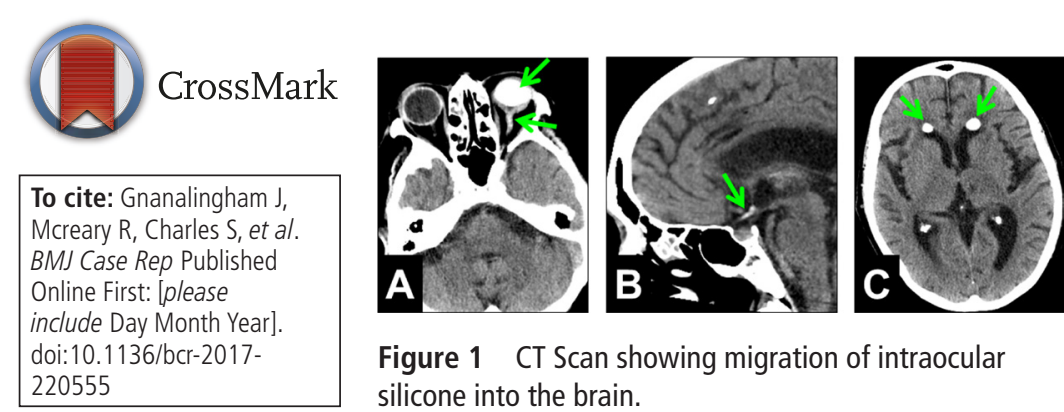

Figure 1 CT Scan showing migration of intraocular silicone into the brain.

\section{Learning points}

- Intraocular silicone oil is used in retinal detachment surgery.

- Silicone oil can migrate along optic nerve into brain and this could be misinterpreted on CT and MR imaging of brain.

associated with bifrontal hyperdense areas within the frontal horns of the lateral ventricles (figure 1C). This was also apparent on the subsequent MR scan. Thus, the bifrontal abnormalities were likely to be secondary to migration of the silicone oil from the left orbit.

Silicone oil is used as an important intravitreal tamponade in the treatment of complicated retinal detachment repair. Migration of the intraocular silicone oil along the optic nerve and into the brain can mimic calcification, haemorrhage and/or tumour leading to misdiagnosis. ${ }^{1}$

Contributors JG:Wrote and revised manuscript. RM: Reviewed radiology and revised manuscript. SC: Ophthalmology care of patient and revised manuscript. KKG: Neurosurgical care of patient and revised manuscript.

Competing interests None declared.

Patient consent Obtained.

Provenance and peer review Not commissioned; externally peer reviewed.

(c) BMJ Publishing Group Ltd (unless otherwise stated in the text of the article) 2017. All rights reserved. No commercial use is permitted unless otherwise expressly granted.

\section{REFERENCES}

1 Grzybowski A, Pieczynski J, Ascaso FJ. Neuronal complications of intravitreal silicone oil: an updated review. Acta Ophthalmol 2014;92:201-4.

Copyright 2017 BMJ Publishing Group. All rights reserved. For permission to reuse any of this content visit http://group.bmj.com/group/rights-licensing/permissions.

BMJ Case Report Fellows may re-use this article for personal use and teaching without any further permission.

Become a Fellow of BMJ Case Reports today and you can:

- Submit as many cases as you like

- Enjoy fast sympathetic peer review and rapid publication of accepted articles

- Access all the published articles

- Re-use any of the published material for personal use and teaching without further permission

For information on Institutional Fellowships contact consortiasales@bmjgroup.com

Visit casereports.bmj.com for more articles like this and to become a Fellow 